\title{
Janusz Gręźlikowski
}

\section{Racje i sens „prawa do obrony” w procesie o nieważność małżeństwa}

Prawo Kanoniczne : kwartalnik prawno-historyczny 53/3-4, 197-222

2010

Artykuł został opracowany do udostępnienia w internecie przez Muzeum Historii Polski w ramach prac podejmowanych na rzecz zapewnienia otwartego, powszechnego i trwałego dostępu do polskiego dorobku naukowego i kulturalnego. Artykuł jest umieszczony w kolekcji cyfrowej bazhum.muzhp.pl, gromadzącej zawartość polskich czasopism humanistycznych i społecznych.

Tekst jest udostępniony do wykorzystania w ramach dozwolonego użytku. 


\section{KS. JANUSZ GRĘŹLIKOWSKI}

Uniwersytet Kardynała Stefana Wyszyńskiego w Warszawie

\section{RACJE I SENS „PRAWA DO OBRONY” W PROCESIE O NIEWAŻNOŚĆ MAŁŻEŃSTWA}

Treść: Wstęp. - 1. Podstawy prawne ,prawa do obrony”. - 2. Podmiot „prawa do obrony”. - 3. „Prawo do obrony” w poszczególnych fazach procesu małżeńskiego i sposoby jego naruszania. - 3.1. Wszczęcie procesu i zawiązanie sporu - faza wstępna procesu. - 3.2. Faza dowodowa procesu. - 3.3. Faza dyskusji sprawy. - 3.4. Faza decyzyjna i zaskarżająca sentencję. - Zakończenie.

\section{Wstęp}

Bardzo wiele miejsca poświęca się dzisiaj w Kościele i w kanonistyce prawom człowieka, ochronie sądowej praw wiernych oraz ,prawu do obrony". Mówi się także o sądownictwie kościelnym w służbie praw człowieka ${ }^{1}$. Kwestie te są szeroko badane, rozpoznawane, interpretowane i komentowane. Także Sługa Boży papież Jan Paweł II - niestrudzony obrońca godności człowieka i jego niezbywalnych praw - wiele miejsca poświęcał w swoim nauczaniu sądowej ochronie praw wiernych, co też sukcesywnie czyni obecny papież - Benedykt XVI. Papież Jan Paweł II w swoim pierwszym przemówieniu, a także i późniejszych, skierowanych do pracowników Trybunału Roty Rzymskiej, zwracał uwagę na zadania Kościoła w przepowiadaniu i chronieniu fundamentalnych praw człowieka, na godność osoby ludzkiej jako fundament tych praw oraz misję i zaangażowanie Kościoła na rzecz właściwej interpretacji realizowania sprawiedliwości i godności człowieka ${ }^{2}$. Przypominał o przysługującemu wiernemu legalnemu dochodzeniu i prawie do obrony na właściwym forum kościelnym.

${ }^{1}$ Zob. R. S z t y c h m i 1 e r, Sadownictwo kościelne $w$ stużbie praw człowieka, Olsztyn 2000.

2 Por. J o a n n e s $\mathrm{P}$ a u $1 \mathrm{u}$ s II, Ad Decanum Sacra Rota ad eiusdemque Tribunalis Praelatos Auditores, ineunte anno iudiciali (17 Februarri 1979), AAS 71(1979), nr 1, s. 422. 
Wskazywał też, iż Kodeks Prawa Kanonicznego przypisuje prawu obrony fundamentalne znaczenie w dochodzeniu obiektywnej prawdy procesowej $^{3}$. Na temat prawa do obrony powstała już w miarę obszerna literatura kanonistyczna ${ }^{4}$.

Kościół określił zasady generalne, które są podstawą procesu oraz służą ochronie praw podmiotowych, będących fundamentem sprawiedliwości w Kościele ${ }^{5}$. Wpisują się one w kontekst nauczania papieskiego i stanowią porządek kanoniczny, którego zadaniem jest ochrona nienaruszalnych i niezbywalnych praw uniwersalnych każdego człowieka ${ }^{6}$. Prawo zaś do obrony przedstawiają na trzech płaszczyznach: jako jedno z praw podstawowych (np. kan. $221 \mathrm{KPK}$ ), na płaszczyźnie deklaracji prawnych (np. kan. 1400-1401, 1671-1691 KPK) oraz płaszczyźnie aplikacji sądowej, jako uprawnienie stron na różnych etapach procesu? ${ }^{7}$. Opracowanie, biorąc pod uwagę normy kodeksowe obowiązujące $\mathrm{w}$ kościelnym prawie procesowym, postanowienia instrukcji procesowej Dignitas connubii z 2005 r. $^{8}$ oraz nauczanie papieskie, pragnie wskazać racje i sens ,prawa do obrony” w kanonicznym procesie o nieważność małżeństwa. Tym samym podejmuje próbę wskazania przyczyn dla których ,prawo do obrony” jest traktowane jako prawo fundamentalne, istotne i ważne dla dojścia do prawdy procesowej, a jednocześnie nie może tej prawdy zakłócić czy deformować.

${ }^{3} \mathrm{~J}$ o a n n e s $\mathrm{P}$ a u 1 u s II, Ad Romanae Rota auditores, officiales et advocatos coram admissos (26 Ianuarii 1989), AAS 81(1989), s. 922-927.

${ }^{4}$ R. S z t y c h m i 1 e r, Prawo do obrony w procesie kanonicznym, w: Finis legis Christus. Księga pamiątkowa dedykowana Księdzu Profesorowi Wojciechowi Góralskiemu z okazji siedemdziesiątej rocznicy urodzin, red. J. Wroceński i J. Krajczyński, T. I, Warszawa 2009, s. 792.

${ }^{5}$ Por. T. R o z k r u t, Ochrona sqdowa praw wiernych - szczegółowe zagadnienia wybrane, w: 25-lecie promulgacji Kodeksu Prawa Kanonicznego. Obowiązywanie i stosowanie w Polsce, red. J. Krukowski i Z. Tracz, Łódź 2009, s. 108-109.

${ }^{6}$ Por. J o a n n e s $\mathrm{P}$ a u $1 \mathrm{u}$ s II, Ad Decanum Sacra Rota ad eiusdemque Tribunalis Praelatos Auditores, ineunte anno iudiciali (17 Februarri 1979)..., nr 1, s. 423.

7 R. S z t y c h m i l e r, Prawo do obrony w procesie kanonicznym..., s. 793.

${ }^{8} \mathrm{P}$ ontificium Cons il i u m de Legum Text ibus, Instructio servanda a tribunalibus dioecesanis et interdioecesanis in pertractandis causis nullitatis matrimonii "Dignitas connubii”, Libreria Editrice Vaticana 2005 (cyt. dalej DC). 


\section{Podstawy prawne ,prawa do obrony"}

Wszystkie prawa przysługujące człowiekowi, w tym także prawo do obrony, swoje źródło biorą w godności osoby ludzkiej, co podkreśla nauczanie Sobóru Watykańskiego II $^{9}$, jak i papieża Jana Pawła II, który w adhortacji Christifideles laici stwierdza, iż „faktyczne uznanie osobowej godności każdej ludzkiej istoty wymaga obrony i poszanowania jej praw" ników Roty Rzymskiej przypominał, że ,powołaniem i zadaniem Kościoła jest ciagły wysiłek, by być orędownikiem godności ludzkiej oraz wskazywać i bronić podstawowych praw człowieka w każdym momencie jego życia"11.

Prawo do obrony nie ma natury prawa samoistnego, a więc nie jest tym samym co poszczególne prawa osoby, w tym prawa wiernego. Stanowi jednak prawo fundamentalne i podstawowe wynikające $\mathrm{z}$ istnienia innych fundamentalnych praw, których ochrona powinna być w Kościele zagwarantowana, a więc gwarantuje ochronę osoby, jej praw i jej dóbr. Wskazuje na to Papieska Komisja Iustitia et Pax w swoim dokumencie „Kościół i prawa człowieka”, gdzie wyliczając katalog praw człowieka, zamieszcza uprawnienie do ochrony prawnej przysługujących człowiekowi praw, także na forum sądowym ${ }^{12}$. Orzecznictwo rotalne $\mathrm{w}$ wielu miejscach potwierdza, iż prawo do obrony pochodzi $z$ prawa naturalnego ${ }^{13}$. Natomiast Jan Paweł II w swoim przemówieniu do pracowników Roty Rzymskiej z 1989 r. zauważa, że prawo do obrony przysługuje każdej stronie procesu, a tym samym nie tylko stronie pozwanej. Prawo do obrony przysługujące stronie powodowej musi być oczywiście wykonywane według słusznych norm prawa pozytywnego, których zadaniem nie jest pozbawienie wykonywania prawa do obrony, ale uregulowanie go w taki sposób, by nie można byłoby go

${ }^{9} \mathrm{KDK}, \mathrm{nr} 19$.

${ }_{10} \mathrm{~J}$ a n P a w e ł II, Adhortacja apostolska Christifideles laici, Wrocław 1995, nr 38 .

${ }_{11}$ Por. J o a n n e s P a 1 u s II, Ad Decanum Sacra Rota ad eiusdemque Tribunalis Praelatos Auditores, ineunte anno iudiciali (17 Februarri 1979)..., nr 1, s. 422.

${ }_{12}$ R. S z t y c h m i 1 e r, Prawo do obrony w procesie kanonicznym..., s. 792.

13 W. K r a i ń s k i, Prawo do obrony w procesie o stwierdzenie nieważności matżeństwa, Ateneum Kapłańskie t. 152(2009) z. 3(601), s. 346. 
nadużywać i w tym samym czasie można byłoby zagwarantować prawo do jego wykonywania ${ }^{14}$.

Prawo, o którym mowa, znalazło swój wyraz w normach Kodeksu Prawa Kanonicznego, zwłaszcza w kan. 221, 1598 § 1, 1614 i 1620. Kan. $221 \S 1$ wskazuje, iż „wiernym przysługuje legalne dochodzenie i obrona przysługujących im w Kościele uprawnień na właściwym forum kościelnym według przepisów prawa". Norma ta bierze pod uwagę przepisy zawarte $\mathrm{w}$ księdze VII Kodeksu dotyczące różnych form procesów, w tym procesów małżeńskich. Jej zaś podstawą stają się dyspozycje kan. 1400 i 1401, w których prawodawca określa zarówno przedmiot postępowania sądowego w Kościele, jak i dokonuje rozróżnienia pomiędzy postępowaniem administracyjnym i sądowym, w których winno być zagwarantowane prawo do obrony.

We wspomnianym kan. 221 ustawodawca kościelny proklamuje zasadę poszanowania dwóch podstawowych uprawnień wiernych: 1. prawa do działania w sądzie, tj. dostępu do sędziego kościelnego w celu przedłożenia swoich racji; 2 . prawa do obrony prawnej przed sądem, którego nie można pojmować tylko jako prawa do „obrony technicznej”, czyli do tego, aby być wspomaganym przez adwokata w sądzie (por. kan. 1481-1490), lecz właściwie jest to gwarancja respektowania kontradyktoryjności (kan. 1513), a także prawa wiernego do usunięcia wszelkiego rodzaju przeszkód (także o charakterze ekonomicznym bezpłatna pomoc - kan. $1649 \S 1,3$ ), które mogłyby mu udaremnić możliwość obrony swoich praw przed sądem ${ }^{15}$. Uprawnienie wiernych wynika - jak już wspomniano - z faktu, iż prawo do wymiaru sprawiedliwości jest podstawowym prawem człowieka i nikt nie może go tego prawa pozbawić. Dlatego prawo do obrony, przysługujące każdej stronie musi być wykonywane według słusznych dyspozycji prawa pozytywnego, którego zadaniem jest nie pozbawianie prawa do obrony, ale regulowanie nim w taki sposób, aby nie doszło do nadużyć czy deformacji prawdy procesowej oraz, aby w tym samym czasie, były zagwarantowane konkretne możliwości do jego wykonywania. Poszanowanie tego prawa zobowiązuje sędziego do zachowania norm proceduralnych, które z kolei gwarantują zachowanie prawa osoby.

${ }_{14} \mathrm{~J}$ o a n n e s $\mathrm{P}$ a u $1 \mathrm{u} \mathrm{s}$ II, Ad Romanae Rotae auditores, officiales et advocatos coram admissos (26 Ianuarii 1989)..., s. 923.

${ }_{15} \mathrm{~W} . \mathrm{K}$ r a i ń s k i, Prawo do obrony w procesie o stwierdzenie nieważności matżeństwa..., s. 347. 
Z przepisu kan. 1598 § 1 KPK wynika z kolei zasada, która winna być zasadą przewodnią całej działalności sądowniczej Kościoła, a mianowicie: ius defensionis semper integrum maneat (prawo do obrony zawsze musi być nienaruszone). Prawo do obrony domaga się poznania dowodów zaprezentowanych przez stronę przeciwną, jak i tych przedłożonych ex officio. Stąd sędzia musi zezwolić stronom oraz ich adwokatom, pod sankcją nieważności, zapoznać się z aktami sprawy w kancelarii trybunału, które nie są im jeszcze znane. Kanon ten postanawia również, że w ,sprawach dotyczących dobra publicznego, sędzia dla uniknięcia bardzo poważnych niebezpieczeństw może zdecydować, że jakiegoś aktu nie należy nikomu ujawniać, z tym zastrzeżeniem, że prawo obrony zostanie zawsze nienaruszone" ${ }^{" 16}$. $Z$ tego wyjątku - jak zaznaczył papież Jan Paweł II w swoim przemówieniu - nie można robić normy generalnej, co miałoby miejsce np. w wyniku poważnego błędu w interpretacji normy kodeksowej ${ }^{17}$.

Podstawą prawną oraz gwarancją zachowania ,prawa do obrony” jest również konieczność opublikowania wyroku, o której mówi norma zawarta w kan. 1614. Papież Jan Paweł II w swoim przemówieniu do Roty Rzymskiej z 1989 r. wprost zapytał: ,jak mogłaby jedna ze stron bronić się w stopniu apelacyjnym przeciwko wyrokowi wydanemu przez trybunał niższego stopnia, jeżeli byłaby pozbawiona prawa do poznania jego motywów zarówno prawnych (in iure), jak i faktycznych (in facto)?"18 Papież, powołując się na powyższy kanon, przypomniał też, że celem lepszego zagwarantowania prawa do obrony, ogłoszony wyrok powinien wskazywać środki, za pomocą których można go podważyć. Nadmienił także, że trybunał pierwszej instancji w realizowaniu wskazanej normy powinien również wskazać możliwości wnoszenia apelacji do Trybunału Roty Rzymskiej jako trybunału drugiej

${ }^{16}$ Kan. 1598 § 1 KPK; Por. T. R o z k r u t, Ochrona sqdowa praw wiernych szczegółowe zagadnienia wybrane..., s. 112.

${ }^{17} \mathrm{~J}$ o a n n e s P a u 1 u s II, Ad Romanae Rota auditores, officiales et advocatos coram admissos (26 Ianuarii 1989)..., s. 925; Por. T. R o z k r u t, Ochrona sqdowa praw wiernych - szczegółowe zagadnienia wybrane..., s. 112.

$18 \mathrm{~J}$ o a $\mathrm{n}$ n e s P a u 1 u s II, Ad Romanae Rota auditores, officiales et advocatos coram admissos (26 Ianuarii 1989)..., s. 926. 
instancji ${ }^{19}$, co bardzo praktycznie rozwija instrukcja Dignitas connubii w artykule $283 \S 1-4^{20}$.

Kan. 1620, nr 7 natomiast mówi o nieważności nieusuwalnej wyroku, jeśli jednej albo drugiej stronie odmówiono prawa do obrony. Zreszta, przepisy kan. 1619-1640 KPK traktujące o zaskarżeniu wyroku, dają możliwość praktycznej realizacji prawa do ochrony prawnej każdego człowieka mającego interes prawny w Kościele ${ }^{21}$. Wspomniane normy prawne, jak i przytoczone nauczanie Jana Pawła II w sposób jednoznaczny wskazuja, jak ważne miejsce posiada ,prawo do obrony” w porządku prawnym Kościoła i jak duże znaczenie mu się przypisuje.

Mówiąc o podstawach prawnych ,prawa do obrony” należy zauważyć, iż istnieje różnica między prawem do obrony, a wykonywaniem tego prawa. Pierwsze stanowi gwarancję respektowania norm proceduralnych przy prowadzeniu procesu o nieważność małżeństwa i respektowania dyspozycji prawa pozytywnego oraz zagwarantowania konkretnych możliwości jego wykonania, oczywiście w ten sposób, aby nie dochodziło do nadużyć i obstrukcjonizmu podczas prowadzenia procesu. Wykonanie zaś tego prawa zależy tylko i wyłącznie od woli strony zainteresowanej ${ }^{22}$. Prawo do obrony ma więc zagwarantować wiernym prawo do poznania prawdy o ich małżeństwie. Należy je interpretować w kontekście obowiązku, jaki mają strony procesowe odnośnie poszukiwania prawdy obiektywnej o ich małżeństwie. Obowiązek ten wyznacza pewne granice prawa do obrony (np. nie należy stosować pomówień, przedkładać fałszywe lub niegodziwe dowody, uchylać się od obecności w sądzie). Prawo do obrony nie oznacza prawa do orzeczenia nieważności małżeństwa lub prawa do jego ważności. Oznacza natomiast - jak stwierdza Jan Paweł II w przemówieniu do Roty Rzymskiej w styczniu 1996 r. - zagwarantowanie stronom ich podstawowych praw procesowych, do których zalicza się prawo złożenia zeznań i innych oświadczeń, prawo przedstawienia dowodów,

19 Tamże, s. 926-927; Por. T. R o z k r u t, Ochrona sqdowa praw wiernych szczegółowe zagadnienia wybrane..., s. 112-113.

20 DC, art. $283 \S 1-4$.

${ }^{21}$ R. S z t y c h m i 1 e r, Prawo do obrony w procesie kanonicznym..., s. 792.

22 Por. kan. $1593 \S 1$ KPK. 
prawo poznania akt procesu oraz prawo przedstawienia stosownych obron $^{23}$.

Możemy zatem powiedzieć, że prawo do pomocy prawnej przysługuje każdemu człowiekowi, który dochodzi swoich praw przed sądem. Tej pomocy prawnej wierni mogą oczekiwać i mogą ją uzyskać w sądach kościelnych. Natomiast omawiane tutaj ,prawo do obrony" pociaga za sobą prawo do obrońcy. Prawo to należy do uprawnień związanych z osobą ludzką i wyprzedza każde prawo stanowione, także procesowe, niezależnie od finalizmu procesu. Oczywiście człowiek może bronić się sam, bez obrońcy. Nie można też przyjąć, iż prawo do obrony zostaje zagwarantowane jedynie przy udziale obrońcy. Jednak implikacje prawa do obrony zależą od możliwości skorzystania w sądzie z pomocy obrońcy. Sąd szanujący prawa człowieka nie może przekreślić możliwości skorzystania z obrońcy. Zaś w systemie prawnym, w którym prawa człowieka nie tylko się chroni, lecz promuje, sąd nie tylko dopuszcza obrońcę, lecz ułatwia skorzystanie z jego usług ${ }^{24}$.

\section{Podmiot "prawa do obrony"}

Kiedy mówiły o racjach i sensie ,prawa do obrony” w procesie o nieważność małżeństwa, to po ukazaniu jego podstaw prawnych, należy wskazać i przybliżyć podmiot tego prawa i jego zdolność procesową. Otóż kan. 1476 stwierdza, że „każdy, zarówno ochrzczony jak i nieochrzczony, może przed sądem występować z powództwem, strona zaś prawnie wezwana powinna odpowiadać". Podstawą zatem zdolności sądowej w Kościele jest nie tylko osobowość kanoniczna, będąca następstwem przyjęcia chrztu, ale również naturalna, oparta na prawie naturalnym. Zdolność sądowa jest źródłem zdolności procesowej, dlatego każdy, kto ma w tym prawny interes, może przed trybunałem kościelnym wystąpić z powództwem w konkretnej sprawie. Inni muszą to prawo uznać i wyrazić zgodę na jego realizowanie. Stąd norma prawna stanowi, że strona prawnie wezwana ma obowiązek odpowiadania, a więc prawnego zareagowania na powództwo, stawienia się w sądzie, odpowiadania na pytania sędziego i uznania prawomoc-

${ }^{23}$ Por. J o a n n e s P a u 1 u s II, Ad Romanae Rota iudices habita (22 Ianuarri 1996), AAS 88(1996), nr 3, s. 775.

${ }^{24}$ R. S o b a ń s k i, Udział adwokata $w$ procesie o nieważność matżeństwa, Ius Matrimoniale 2(1997), s. 141. 
nego orzeczenia sędziego ${ }^{25}$. Instrukcja Dignitas connubii zachęca, aby obydwoje małżonkowie wzięli udział w procesie, gdyż ich obecność ułatwi poznanie prawdy i lepiej zagwarantuje prawo do obrony ${ }^{26}$.

Przede wszystkim strony procesowe: powodowa i pozwana, są podmiotem „prawa do obrony”, jednakże mogą mieć ustanowionego kuratora lub też mogą swobodnie ustanowić swojego pełnomocnika procesowego lub adwokata ${ }^{27}$. Należy jednak pamiętać o przepisie kan. 1477, który stwierdza, że strony choćby ustanowiły pełnomocnika lub adwokata, zawsze są obowiązane stawić się w sądzie osobiście, jeżeli żąda tego przepis prawa lub sędzia ${ }^{28}$. Z normy tej wynika, że np. przysięgę można w sądzie złożyć zawsze tylko osobiście ${ }^{29}$, a także niektórych niezbędnych i ważnych wyjaśnień dla sądu w sprawach małżeńskich ${ }^{30}$.

Jeżeli chodzi o kuratora, to jest to osoba wyznaczona urzędowo do sprawowania opieki prawnej nad osobą niezdolną do działań prawnych, czyli do sprawowania nad nią kurateli, czyli występuje w sądzie w imieniu małoletnich lub pozbawionych używania rozumu, którzy nie posiadają zdolności do podejmowania czynności procesowych ${ }^{31}$. Wyjątek stanowią sprawy duchowe ${ }^{32}$. „Pozbawieni zarządu majątkiem i ci, którzy nie używają w pełni rozumu, mogą osobiście występować w sądzie, tylko by odpowiadać za własne przestępstwa lub z nakazu sędziego; w pozostałych sprawach - jak zaznacza ustawodawca - muszą występować i odpowiadać przez swoich kuratorów"33. Sędzia kościelny może tutaj uwzględnić orzeczenie sądu świeckiego w sprawie ubezwłasnowolnienia osoby. $\mathrm{W}$ razie zaś potrzeby, mając ku temu przekonywujące i prawdziwe przesłanki, sam może potraktować stronę jako ubezwłasnowolnioną. Jednocześnie, jeżeli wymaga tego

${ }^{25}$ DC, art. 95; W. K r a i ń s k i, Prawo do obrony w procesie o stwierdzenie nieważności malżeństwa..., s. 347-348.

${ }^{26} \mathrm{DC}$, art. $95 \S 1$.

${ }^{27} \mathrm{DC}$, art. $103 \S 1$.

${ }^{28}$ Kan. 1477 KPK; Por. DC, art. 96.

29 Zob. kan. 1532 KPK.

${ }^{30}$ T. P a w 1 u k, Prawo kanoniczne wedtug Kodeksu Jana Pawła II. Doczesne dobra Kościoła, sankcje karne w Kościele, procesy, Olsztyn 1990, t. IV, s. 221.

${ }^{31}$ Kan. 1478 § 1 KPK; DC, art. 98-100; R. S z t y c h m i 1 e r, Sqdownictwo kościelne w stużbie praw człowieka..., s. 118.

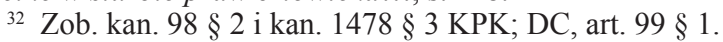

${ }^{33}$ Kan. 1478 § 4 KPK. 
wyjaśnienie sprawy, może wezwać osobę ubezwłasnowolnioną do są$\mathrm{du}^{34}$. Możliwe jest dopuszczenie kuratora ustanowionego przez władzę świecką do występowania w imieniu strony, jednakże - jeśli jest to możliwe - po wysłuchaniu zdania biskupa diecezjalnego tejże strony. Gdyby jednak takiego kuratora nie było albo istniały racje za jego niedopuszczeniem, sędzia powinien wyznaczyć osobnego kuratora do występowania $\mathrm{w}$ danej sprawie ${ }^{35}$. Zatem dopuszczenie kuratora, już ustanowionego przez władzę świecką, nie wymaga zgody własnego ordynariusza strony, dopuszcza go sam sędzia, wysłuchawszy, jeśli nic nie stoi na przeszkodzie, zdania biskupa diecezjalnego strony. Również sam sędzia, a nie ordynariusz, jeżeli zachodzi potrzeba, ustanawia nowego kuratora ${ }^{36}$. Należy zauważyć, że ustawowy przedstawiciel strony może sam posłużyć się pełnomocnikiem lub adwokatem. Niekiedy powołanie ich, jeżeli domaga się tego dobro wyjaśnienia sprawy, sędzia może uznać za konieczne ${ }^{37}$. Instrukcja Dignitas connubii dodaje, że wydany przez sędziego dekret w sprawie kuratora, powinien być podany do wiadomości wszystkim zainteresowanym, włącznie z małżonkiem, któremu dano kuratora, chyba że sprzeciwiają się temu poważne racje, z poszanowaniem jednak prawa do obrony ${ }^{38}$.

Strona procesowa, której przysługuje zdolność procesowa, poza wypadkami określonymi w prawie, może swobodnie ustanowić sobie w procesie o nieważność małżeństwa pełnomocnika ${ }^{39}$. Jest to osoba, która na mocy zlecenia strony procesowej występuje w jej imieniu i w zastępstwie, na podstawie udzielonego jej pełnomocnictwa ${ }^{40}$. Może też spełniać czynności procesowe, których skutki dotyczą osoby reprezentowanej ${ }^{41}$. W zasadzie może on robić wszystko to, co przynale-

${ }^{34}$ T. P a w 1 u k, Prawo kanoniczne wedlug Kodeksu Jana Pawła II..., t. IV, s. 222-223.

${ }_{35}$ Zob. kan. 1479 KPK; Por. R. S z t y c h m i 1 e r, Sadownictwo kościelne w stużbie praw człowieka..., s. 119.

${ }^{36}$ T. P a w 1 u k, Prawo kanoniczne wedtug Kodeksu Jana Pawła II..., t. IV, s. 223.

${ }^{37} \mathrm{~W} . \mathrm{K} \mathrm{r}$ a i ń s k i, Prawo do obrony w procesie o stwierdzenie nieważności matżenstwa..., s. 348.

38 DC, art. $99 \S 2$.

39 Kan. 1481 § 1 KPK; DC, art. $103 \S 2$.

${ }^{40}$ Por. DC, art. 104 i $106 \S 1$.

${ }^{41}$ R. S z t y c h m i l e r, Sqdownictwo kościelne w stużbie praw człowieka..., s. 123. 
ży się samej stronie sporu, poza kilkoma wyjątkami. Bez specjalnego zlecenia pełnomocnik nie może się ważnie zrzec skargi, instancji albo aktów sądowych ani też zawierać ugody, uciekać się do sądu polubownego oraz podejmować działań zabronionych mu na mocy prawa lub szczegółowym zleceniem ${ }^{42}$. Głównym celem więc pełnomocnika jest występowanie w procesie w zastępstwie strony procesowej. Działa on w ramach zlecenia udzielonego mu przez stronę sporu, które określa i wytycza podstawowy obowiązek procesowy. Prawo pozwala mu na obecność podczas przesłuchania świadków, gdy sprawa dotyczy dobra publicznego ${ }^{43}$. Normy kodeksowe przewidują możliwość ustanowienia przez stronę procesową tylko jednego pełnomocnika ${ }^{44}$. Gdyby jednak strona procesowa, jak zaznacza Instrukcja Dignitas connubii, ze względu na słuszną rację, ustanowiła sobie więcej niż jednego pełnomocnika, wówczas sposób ich powoływania powinien być taki, aby między nimi mogła być zachowana zasada wyprzedzenia ${ }^{45}$. Jeżeli obydwie strony proszą o stwierdzenie nieważności ich małżeństwa mogą ustanowić sobie wspólnego pełnomocnika ${ }^{46}$.

Co do adwokata, to jego zadaniem jest służenie stronie procesowej pouczeniem i radą oraz bronienie jej poprzez ukazywanie faktów i przytaczanie odpowiednich przepisów prawa ${ }^{47}$, a więc doradztwo prawne oraz wskazywanie odpowiednich norm prawnych, z których strona może korzystać $\mathrm{w}$ udowadnianiu przed sądem swoich twierdzeń. Strony procesowe $\mathrm{w}$ procesie o nieważność małżeństwa mogą ustanowić sobie swobodnie adwokata ${ }^{48}$, za wyjątkiem spraw o dyspensę od małżeństwa niedopełnionego ${ }^{49}$. Strona może nawet ustanowić kilku adwokatów w tej samej sprawie ${ }^{50}$. Również przedstawiciel ustawowy strony procesowej może posłużyć się adwokatem. Adwokatowi - zgodnie z zapisem instrukcji Dignitas connubii - można też powie-

${ }^{42}$ Kan. 1485 KPK; W. K r a i ń s k i, Prawo do obrony w procesie o stwierdzenie nieważności matżeństwa..., s. 349.

${ }^{43}$ Kan. 1559 KPK; DC, art. $104 \S \S 1-2$.

${ }^{44}$ Kan. $1482 \S 1$ KPK; DC, art. $103 \S 3$.

${ }^{45} \mathrm{DC}$, art. $103 \S 3$.

${ }^{46} \mathrm{DC}$, art. $103 \S 4$.

${ }^{47}$ T. P a w 1 u k, Prawo kanoniczne wedlug Kodeksu Jana Pawła II..., t. IV, s. 225 .

${ }^{48}$ Kan. $1481 \S 1$ KPK; DC, art. $106 \S 1$.

${ }^{49}$ Zob. kan. $1701 \S 2$ KPK.

${ }^{50}$ Kan. $1082 \S 3$ KPK; DC, art. $103 \S 4$. 
rzyć pełnienie funkcji pełnomocnika ${ }^{51}$. Z przepisu kan. $1620 \mathrm{nr} 7$ wynika, że nikomu nie wolno odmówić wzięcia sobie adwokata, gdyż odmowa którejkolwiek stronie prawa do obrony powoduje nieusuwalną nieważność wyroku. Każda strona sporu ma też prawo do obrony w każdym etapie procesu ${ }^{52}$. Można powiedzieć, że prawodawca kościelny kładzie obecnie większy nacisk na udział adwokatów w procesach kościelnych, w tym i w procesie małżeńskim. Zgodnie z kan. $1678 \S 1 \mathrm{KPK} w$ procesie małżeńskim przewidziany jest udział obrońcy, którym jest adwokat. Jego udział jest ważny dlatego, iż może on być obecny przy przesłuchaniu stron, świadków i biegłych, czego nie może strona procesowa. Gdyby strona nie wybrała adwokata, sędzia może go mianować z urzędu ${ }^{53}$. Instrukcja Dignitas connubii, przewiduje powołanie adwokata przez przewodniczącego kolegium sędziowskiego. Zachodzi to wtedy, kiedy przewodniczący kolegium uzna, że jego obecność w postępowaniu sądowym jest konieczna, a strona procesowa w wyznaczonym jej czasie nie dokonała tego lub też w przypadku przyznania stronie procesowej bezpłatnej pomocy sądowej ${ }^{54}$. Instrukcja jednocześnie stwierdza, że jeżeli obydwie strony proszą o stwierdzenie nieważności ich małżeństwa, wówczas mogą ustanowić sobie wspólnego adwokata ${ }^{55}$.

Prawodawca kościelny stawia adwokatom konkretne wymagania. Może nim być osoba pełnoletnia o nienaruszonej sławie i moralności; powinna być katolikiem, doktorem prawa kanonicznego lub prawdziwie biegłym w tej dziedzinie oraz zatwierdzonym przez biskupa diecezjalnego ${ }^{56}$. Wynika to $\mathrm{z}$ faktu, iż zadanie adwokata definiowane jest jako munus i jako officium mające charakter kościelny i posiadające pewne cechy urzędu kościelnego, będącego na służbie Kościołowi. Poza tym urząd adwokata ma charakter publiczny, który winien mieć na uwadze ducha i własne cele kanonicznego porządku prawnego ${ }^{57}$.

${ }^{51}$ DC, art. $103 \S 1$.

${ }^{52}$ R. S z t y c h m i 1 e r, Sqdownictwo kościelne w służbie praw człowieka..., s. 132 .

53 Kan. $1481 \S 3$ KPK.

${ }^{54} \mathrm{DC}$, art. $101 \S 3$ i art. $112 \S 2$.

${ }_{55} \mathrm{DC}$, art. 102.

${ }^{56}$ Kan. 1490 KPK; R. S z t y c h m i 1 e r, Sadownictwo kościelne w stużbie praw czlowieka..., s. 133-134.

${ }^{57}$ A. G. M i z i ń s k i, Adwokat gwarantem prawa do obrony $w$ procesie kanonicznym, w: Władza i urzędy sądowe - władza i służba. Materiały z ogólnopolskiego 
Adwokat jako strona procesu może występować w procesie jedynie w zakresie możliwości udzielonych mu przez stronę w zleceniu, które ma charakter mandati ad lites $^{58}$. Pomaga on stronie w redagowaniu skargi powodowej i określeniu podstawy prawnej, by zaskarżyć ważność małżeństwa, wskazuje jakie należy przedłożyć sądowi środki dowodowe, na co zwrócić uwagę podczas przesłuchania, składa zarzuty oraz odpowiada na argumenty strony przeciwnej, poucza o terminach sądowych i celowości nowych środków dowodowych, zabiega również o stawiennictwo świadków. Zostaje on wprowadzony w realia sporu i ma za zadanie towarzyszenie stronie $\mathrm{w}$ prowadzonym procesie w celu udzielania porad prawnych na każdym jego etapie. Może być obecny przy zeznaniach stron i świadków, może przejrzeć akta sprawy w trybunale w czasie wyznaczonym na publikację, jak też ma obowiązek dokładnie się z nimi zapoznać i przygotować obrony ${ }^{59}$.

Należy zauważyć, że w sprawach o stwierdzenie nieważności małżeństwa nie ma konieczności występowania w nich adwokata, tak jak to jest $w$ przypadku procesu karnego. Jednakże prawodawca kościelny wyraźnie domaga się udziału adwokatów w procesach o nieważność małżeństwa, zauważając przede wszystkim racje praktyczne ich udziału, jak i realizowania ,prawa do obrony”. Stąd, uzasadniając niejako racje i sens ,prawa do obrony”, instrukcja Dignitas connubii stwierdza, że zadaniem biskupa diecezjalnego sprawującego nadzór nad sądem jest podanie do publicznej wiadomości listy adwokatów dopuszczonych do występowania $\mathrm{w}$ jego sądzie oraz listy pełnomocników procesowych działających zazwyczaj w tymże sądzie w imieniu stron ${ }^{60}$. Instrukcja przypomina jednocześnie, że w każdym sądzie - o ile to możliwe - powinno się ustanowić stałych adwokatów, opłacanych przez sąd, którzy mogliby pełnić zadania adwokata i pełnomocnika na rzecz stron, które zechciałyby ich wybrać ${ }^{61}$. Zaznacza także, aby przy każdym sądzie istniała i działała poradnia prawna, bądź jako urząd,

spotkania pracowników sądownictwa kościelnego w Gródku nad Dunajcem w dniach 11-12 października 2004 roku, red. T. Rozkrut, Tarnów 2005, s. 37-38.

${ }^{58}$ Kan. $1484 \S 1$ KPK; Por. DC, art. 111; Por. W. K r a i ń s k i, Prawo do obrony w procesie o stwierdzenie nieważności małzeństwa..., s. 350.

${ }_{59} \mathrm{~W} . \mathrm{K}$ r a i ń s k i, Prawo do obrony w procesie o stwierdzenie nieważności matzeństwa..., s. 350-351.

${ }^{60} \mathrm{DC}$, art. $112 \S 1$.

${ }^{61} \mathrm{DC}$, art. $113 \S 3$. 
bądź jako konkretna osoba, w której każdy zainteresowany mógłby swobodnie i szybko uzyskać poradę prawną na temat możliwości wniesienia sprawy o nieważność małżeństwa i na temat ewentualnego sposobu postępowania ${ }^{62}$.

\section{3. „Prawo do obrony” w poszczególnych fazach procesu małżeńskiego i sposoby jego naruszania}

Mając na uwadze przepisy kanonicznego procesu małżeńskiego możemy powiedzieć, że istnieje wiele możliwości naruszenia prawa strony procesowej do obrony. Jest nim złamanie każdego przepisu gwarantującego stronie jakąś konkretną formę ochrony jej praw. Jak wspomniano wyżej, w myśl przepisu kan. $1620 \mathrm{nr} 7$, nikomu nie wolno odmówić prawa do obrony, gdyż powoduje to nieusuwalną nieważność wyroku. Oczywiście, do ważności procesu o nieważność małżeństwa nie jest wymagane faktyczne skorzystanie stron procesowych z prawa do obrony, ale zagwarantowanie przez sąd tej możliwości. Gwarancje te dotyczą poszczególnych faz procesu, a strona ma prawo do obrony w każdym etapie procesu. Zatem zainteresowana strona procesowa może bronić i korzystać ze swojego uprawnienia opartego na przepisie prawa kanonicznego na różnych etapach procesu, począwszy od prośby o wszczęcie procesu i zawiązania sporu, w fazie dowodowej procesu, fazie dyskusji oraz etapie decyzji.

\subsection{Wszczęcie procesu i zawiązanie sporu - faza wstępna procesu}

Postępowanie procesowe o nieważność małżeństwa rozpoczyna się od złożenia skargi powodowej odpowiadającej wymogom prawa ${ }^{63}$, która powinna być skierowana do kompetentnego sędziego ${ }^{64}$. Sędzia, zgodnie z art. 114 instrukcji Dignitas connubii, nie może rozpoznać żadnej sprawy, dopóki nie zostanie przedstawiona prośba przez tego,

${ }^{62} \mathrm{DC}$, art. 113 § 1; Por. W. K i w i o r, Zasady działania obowiazujace $w$ sqdach $i$ strony procesowe, w: Proces małżeński według instrukcji „Dignitas connubii”. Materiały z ogólnopolskiego spotkania pracowników sądownictwa kościelnego w Gródku nad Dunajcem w dniach 13-14 czerwca 2005 roku, red. T. Rozkrut, Tarnów 2006, s. 71-72.

${ }^{63}$ Zob. kan. 1501-1504 KPK.

${ }^{64}$ Kan. 1673 KPK; DC, art. 10-11. 
kto ma prawo zaskarżyć małżeństwo ${ }^{65}$. Przyczyną złożenia skargi winno być przekonanie strony powodowej o słuszności swoich roszczeń, które powinno zostać poparte przytoczeniem faktów i dowodów potwierdzających to przekonanie i uprawnienie. Na etapie skargi powodowej, adwokat może służyć stronie swoją fachową pomocą, pomagając w redagowaniu skargi i sprecyzowaniu tytułu sprawy; występuje on wtedy bardziej w roli doradcy prawnego niż adwokata w sensie formalnym ${ }^{66}$.

W dekrecie przyjmującym skarge powodową przewodniczący kolegium sędziowskiego powinien, zgodnie z art. $126 \S 1$ instrukcji Dignitas connubii, wezwać, czyli pozwać przed sąd pozwanego ustalając czy ma on odpowiedzieć na piśmie na żądania powoda, czy też stawić się przed trybunałem ${ }^{67}$. Racją przepisu dotyczącego cytacji jest zapewnienie sprawiedliwej obrony własnych praw i określenia przedmiotu sporu ${ }^{68}$. Czy jednak w przypadku braku wezwania strony pozwanej będziemy mieli do czynienia z odmową prawa do obrony, o czym, mówi kan. 1620 nr 7 KPK? Wskazywana instrukcja w art. 128 stwierdza, że brak wezwania strony pozwanej powoduje, o ile sama nie stawiła się w sądzie, nieważność akt procesowych, a w konsekwencji nieważność wyroku ${ }^{69}$. Jest to jednak nieważność usuwalna, a zatem nie ta o której mówi prawodawca kodeksowy w przypadku odmowy prawa do obrony. Mamy więc do czynienia z inną formą nieważności wyroku, zwłaszcza że nawet jeśli wyrok będzie nieważny z powodu braku cytacji strony pozwanej, nie oznacza to, że strona ta nie może mieć wiedzy o złożonej przez powoda skardze powodowej. Można zatem powiedzieć, że jakkolwiek brak wezwania powoduje nieważność wyroku, to nie jest to nieważność z powodu odmowy prawa do obrony. Można jednak mieć wątpliwość czy w przypadku gdy strona pozwana nie ma faktycznie wiedzy o złożonej przez powoda skardze powodo-

${ }^{65}$ Por. kan. 1501 KPK; DC, art. 92-93 i 114; Por. H. S t a w n i a k, Wprowadzenie sprawy i zakończenie instancji wedlug instrukcji "Dignitas connubii", w: Proces małżeński według instrukcji „Dignitas connubii”..., s. 76-77; R. S z t y c h m i 1 e r, Prawo do obrony w procesie kanonicznym..., s. 795-796.

${ }^{66} \mathrm{~W}$. K r a i ń s k i, Prawo do obrony w procesie o stwierdzenie nieważności matżeństwa..., s. 351.

${ }^{67}$ Por. kan. 1508 § 1 KPK.

${ }^{68}$ Por. H. S t a w n i a k, Wprowadzenie sprawy i zakończenie instancji wedtug instrukcji “Dignitas connubii”..., s. 82.

${ }_{69}$ Zob. kan. 1622, nr 5 KPK. 
wej o nieważności małżeństwa, brak cytacji rzeczywiście nie oznacza odmowy prawa do obrony? Opinie kanonistów co do rozstrzygnięcia tej kwestii są różne. Zdaniem G. Erlebacha działania sędziego w odniesieniu do zapewnienia prawa do obrony stronie pozwanej muszą wykluczać negację tegoż prawa, która miałaby miejsce w przypadku braku pewnej cytacji strony pozwanej ${ }^{70}$. Wydaje się, że można przyjąć, iż brak cytacji strony sam w sobie powoduje jedynie nieważność usuwalną wyroku i nie jest w czystej formie odmową prawa do obrony, to jednak tenże brak cytacji świadczy o tym, że już od początku działania procesowe strony pozwanej poddane zostały pewnemu ograniczeniu. Należy zauważyć, że nie można mówić o odmowie prawa do obrony jeśli sędzia powiadomi później stronę pozwaną o przedmiocie zawiązania sporu lub strona pozwana rzeczywiście wie o złożonej skardze i sama stawi się w sądzie. Należy jednak mieć pewność, którą daje akt pozwania sądowego ${ }^{71}$.

Jeżeli mówimy o prawie do obrony na tym etapie procesu, to musimy też rozważyć kwestię odnoszącą się do dostarczenia stronie pozwanej skargi powodowej ${ }^{72}$. W myśl art. $127 \S 3$ instrukcji Dignitas connubii do wezwania sądowego należy dołączyć zasadniczo skargę powodową, chyba że przewodniczący lub sędzia, z ważnych racji, uzna inaczej. W tym przypadku należy jednak pozwanemu przedstawić przedmiot sprawy i motywy skargi dołączone przez powoda ${ }^{73}$. Można stwierdzić, że brak przedstawienia skargi powodowej stronie pozwanej ogranicza równą pozycję stron $\mathrm{w}$ procesie $\mathrm{w}$ odniesieniu do samego sporu, to jednak jest on zagwarantowany prawem sędziego w szczególnych przypadkach, a zatem nie może być traktowany jako odmowa prawa do obrony, gdyż czasami brak wspomnianego załączenia skargi powodowej może być pożyteczny dla poznania prawdy obiektywnej o małżeństwie stron. Celem jednak zachowania prawa do obrony i równości procesowej stron, skarga powodowa winna być udostępniona stronie przy okazji przesłuchania.

Należy również zauważyć, iż zgodnie z kan. 1677 § 2 KPK i art. 135 $\S 1$ instrukcji, po upływie piętnastu dni od zawiadomienia o dekrecie

\footnotetext{
${ }^{70}$ Por. G. E r 1 e b a c h, Il giudice e il diritto di difesa delle parti, w: Il diritto di difesa nel processo matrimoniale canonico, Città del Vaticano 2006, s. 104-106.

71 Zob. DC, art. $130 \S 1$.

72 Por. kan. 1507, 1508 § 2 KPK.

73 Por. kan. 1508 § 2 KPK.
} 
cytacyjnym przewodniczący lub ponens powinien w ciągu dziesięciu dni dekretem sformułować wątpliwość, a więc określić z jakiego tytułu lub tytułów zaskarża się ważność małżeństwa stron. Dekret ten powinien być, zgodnie z art. $135 \S 4$ Instrukcji, podany do wiadomości stron, które jeśli nie wyraziły wcześniej zgody, mogą w ciagu dziesięciu dni odwołać się do kolegium sędziowskiego, by dekret został zmieniony ${ }^{74}$. Można postawić pytanie, czy brak wspomnianej czynności procesowej oznacza odmowę prawa do obrony? Kanoniści nie udzielają zgodnej odpowiedzi na tak sformułowane pytanie. Niektórzy twierdzą, że nie zostaje naruszone prawo do obrony, gdyż sędzia nie ma prawa formułować przedmiotu zawiązania sporu z własnej inicjatywy, a czyni to tylko w oparciu o tytuły podane przez strony w skardze powodowej lub też w odpowiedzi strony pozwanej na dekret cytacji. Takie działanie ma charakter czysto techniczny ${ }^{75}$. Jeżeli sędzia określiłby samoistnie przedmiot sporu, a więc nie w oparciu o tytuły określone przez strony, wyrok będzie dotknięty wadą nieważności nieusuwalnej, o której mówi kan. 1620, nr 4 KPK, oczywiście przy założeniu, ze strona pozwana została zgodnie z prawem pozwana do sądu poprzez akt cytacji. Inni kanoniści uważają, że w przypadku braku powiadomienia o dekrecie zawiązania sporu można mówić o odmowie prawa do obrony, gdyż zostaje postawiona w wątpliwość idea sporności procesu, nie tylko charakterystyczna dla procesu o stwierdzenie nieważności małżeństwa, ale wręcz fundamentalna ${ }^{76}$.

\subsection{Faza dowodowa procesu}

W kontekście omawianego sensu i racji „prawa do obrony” w procesie o nieważność małżeństwa, w fazie dowodowej procesu uprawnienie to realizowane jest przede wszystkim poprzez:

- prawo do obecności podczas przesłuchania stron, świadków i biegłych $^{77}$, przy czym sędzia, z powodu okoliczności osób i rzeczy, może zarządzić inaczej ${ }^{78}$;

${ }^{74}$ Por. H. S t a w n i a k, Wprowadzenie sprawy $i$ zakończenie instancji wedtug Instrukcji „,Dignitas connubii”..., s. 84.

${ }^{75}$ Por. S. G h e r r o, Il diritto alla difesa nei processi matrimoniali canonici, Monitor Ecclesiasticus 113(1988), s. 12.

${ }_{76}$ Por. M.J. A r r o b a C o n d e, Diritto processuale canonico, Roma 1993, s. 313.

${ }^{77}$ Kan. 1678 § 1 , nr 1 KPK.

${ }^{78}$ Kan. 1559 KPK. 
- prawo do stawiania za pośrednictwem sędziego pytań świadkom ${ }^{79}$;

- prawo do przeglądania akt procesowych, nawet przed ich publikacją i prawo do możliwości zapoznania się $\mathrm{z}$ dowodami przedłożonymi przez strony ${ }^{80}$;

- prawo do przeglądania akt procesowych, które nie są jeszcze znane oraz prawo do otrzymania odpisów akt sprawy podczas publikacji ${ }^{81}$;

- prawo do zapoznania się podczas publikacji z aktami, których utajnienie przed stronami sędzia uzna za konieczne, po uprzednim złożeniu przysięgi lub przyrzeczenia zachowania tajemnicy ${ }^{82}$.

Mając na uwadze powyższe, można w kontekście racji i sensu ochrony „prawa do obrony” postawić kilka pytań odnoszących się do: konieczności przesłuchania stron procesowych, prawa stron do proponowania różnych środków dowodowych, możliwości zapoznania się stron $\mathrm{z}$ aktami procesowymi w trakcie trwania postępowania dowodowego, utajnienia pewnych akt sprawy.

Najpierw należy postawić pytanie czy istnieje konieczność przesłuchania stron procesowych? Zgodnie z kan. 1530 KPK sędzia zawsze może przesłuchać strony i powinien to uczynić na wyraźne żądanie strony lub dla udowodnienia faktu, który ze względu na interes publiczny wymaga usunięcia wattpliwości. Instrukcja Dignitas connubii używa określenia bardziej obligatoryjnego, kładąc akcent na możliwość przesłuchania stron przez sędziego celem dokładnego poznania prawdy $^{83}$. Z zapisu kodeksowego można wywnioskować, iż przesłuchanie stron nie jest obligatoryjne, poza wskazanymi przypadkami i pozostawione jest osądowi sędziego. Natomiast Instrukcja sugeruje, że jest ono obowiązkowe. Na ogół jednak sędziowie dążąc do wyjaśnienia prawdy procesowej „robią wszystko”, ażeby strony procesowe zostały przesłuchane. Jest to istotne i wskazane przede wszystkim dla ustalenia określonych faktów, które najlepiej znają strony procesowe, jak też dla całej instrukcji sprawy. Zrezygnowanie z zeznań stron, co jest niespotykane w praktyce sądowniczej, byłoby pozbawieniem się przez sędziego możliwości rzetelnej oceny faktów i dotarcia do obiek-

\footnotetext{
${ }^{79}$ Kan. 1561 KPK.

${ }^{80}$ Kan. 1678 \& 1, nr 2 KPK.

${ }^{81}$ Kan. 1598 § 1 KPK; Zob. DC, art. $235 \S 1$.

${ }^{82}$ DC, art. 234.

${ }^{83}$ Zob. DC, art. 177.
} 
tywnej prawdy o rozpatrywanym małżeństwie ${ }^{84}$. Gdyby zaś sędzia uznał wspomniane przesłuchanie za niekonieczne wydaje się, że nie będziemy mieli z odmową prawa do obrony, gdyż motywacja strony powodowej określona jest $\mathrm{w}$ skardze powodowej, a strona pozwana zawsze może odpowiedzieć na cytację na piśmie ${ }^{85}$.

Do istoty „prawa do obrony” należy zapewne prawo stron do proponowania i przedstawiania sędziemu różnych środków dowodowych. Stanowi to podstawową wartość procesu o nieważność małżeństwa i wskazuje, iż strony mają zapewnione prawo obrony własnych interesów, jak też umożliwia poznanie prawdy obiektywnej o małżeństwie stron. Strony powinny mieć tutaj zapewnioną swobodę w zgłaszaniu dowodów. Ich wartość i ostateczna ocena należy przecież i tak do sędziego ${ }^{86}$. Niedopuszczenie dowodów godziwych, uzasadnionych i koniecznych może być formą odmowy prawa do obrony, jak też nie powiadomienie adwokata o terminach planowanych przesłuchań, nieuwzględnienie jego wniosków o dostosowanie terminu przesłuchań do jego możliwości, niedopuszczenie adwokata do przedstawiania dodatkowych pytań lub nie zapisywanie w protokole istotnych dla sprawy zeznań stron i świadków. Odmową prawa do obrony może być również niedopuszczenie konkretnych środków dowodowych, gdy ich związek ze sprawa jest niewattpliwy, a w sprawie nie dostarczono jeszcze zbyt dużej ilości środków dowodowych ${ }^{87}$.

Zagwarantowaniem ,prawa do obrony” jest możliwość zapoznania się stron z aktami procesowymi. Jeżeli chodzi o zapoznanie się w trakcie trwania postępowania dowodowego, to wydaje się, że odmowa tej czynności nie stanowi odmowy prawa do obrony, gdyż kan. 1598 $\S 1$ KPK oraz art. $229 \S 3$ instrukcji Dignitas connubii stwierdzają, iż po zebraniu dowodów, sędzia pod sankcją nieważności musi dekretem zezwolić stronom i ich adwokatom na przejrzenie akt, które nie są im znane, w kancelarii trybunału. Przepis ten jest oczywistym zagwarantowaniem prawa do obrony, którego naruszenie, zgodnie z kan. 1620, nr 7 KPK powoduje nieusuwalną nieważność wyroku. Instrukcja

${ }^{84}$ T. R o z k r u t, Dowody, w: Komentarz do Instrukcji procesowej „Dignitas connubii”, red. T. Rozkrut, Sandomierz 2007, s. 255.

${ }^{85}$ Zob. kan. 1513 \& 1 i 2 KPK.

${ }^{86}$ R. S z t y c h m i 1 e r, Prawo do obrony w procesie kanonicznym..., s. 800801.

87 Tamże, s. 804-805. 
Dignitas connubii $\mathrm{w}$ art. 231 stwierdza natomiast, że naruszenie przepisu art. 229 § 3, a więc traktującego o możliwości przejrzenia akt procesowych, prowadzi do nieważności usuwalnej wyroku, w przypadku zaś odmówienia prawa do obrony, nieważności nieusuwalnej. Wynika $\mathrm{z}$ tego, że naruszenie tego przepisu może powodować nieważność usuwalną lub nieusuwalną wyroku, a zatem nie w każdym przypadku można mówić o odmowie prawa do obrony ${ }^{88}$. Jeśli zatem odmowa przejrzenia akt uniemożliwia wykonanie prawa do obrony stronie jest oczywiste, ze mamy do czynienia z nieważnością nieusuwalną wyro$\mathrm{ku}^{89}$. W innych sytuacjach można mówić tylko o usuwalnej nieważności wyroku. Oznacza to, że z zasady brak publikacji akt powoduje jedynie nieważność usuwalną wyroku, o ile strona pomimo tego braku pozna dowody wyprodukowane w procesie. Jeśli zaś nie, wtedy brak wiedzy o tychże dowodach skutkuje odmową prawa do obrony, gdyż strona nie jest w stanie ustosunkować się do dowodów czy też aktów, których nie była w stanie poznać.

Art. 230 instrukcji Dignitas connubii stanowi, że sędzia, dla uniknięcia bardzo poważnych niebezpieczeństw może zdecydować, iż jakiegoś aktu nie należy nikomu ujawniać z tym zastrzeżeniem, że prawo do obrony zostanie zawsze nienaruszone. Oznacza to, że jest możliwa publikacja jedynie częściowa, pod warunkiem że utajnienie jakiegoś aktu nie przyczyni się do niepełnego poznania sprawy przez stronę ${ }^{90}$. Jest to oczywiście wyjątek od ogólnej zasady, zawartej w kan. 1598 KPK i art. $229 \S 3$ instrukcji, i nie może być traktowany jako zasada. Dlatego art. 234 instrukcji zaznacza, że jeśli sędzia, dla uniknięcia najbardziej poważnych niebezpieczeństw, utrzymuje że jakiegoś aktu nie należy ujawniać stronom, taki akt może być przejrzany przez adwokatów stron, po uprzedniej przysiędze lub przyrzeczeniu zachowania tajemnicy. Co więcej, sędzia ma prawo w świetle art. $232 \S 1$ zobowiązać strony do złożenia przysięgi lub przyrzeczenia, aby z pozyskanej wiedzy korzystały jedynie w celu wykonywania prawa do obrony na forum sądowym. W przypadku odmowy złożenia przysięgi, czy też przyrzeczenia, zgodnie z art. $232 \S 2$ zakłada się, ze strona zrzekła się możliwości przejrzenia akt.

${ }^{88}$ A. D z i ę g a, Sprawy wpadkowe, publikacja akt, dyskusja sprawy (art. 217245), w: Proces małżeński według instrukcji „Dignitas connubii”..., s. 117-118.

${ }_{89}$ Zob. kan. 1620, nr 7 KPK.

${ }^{90}$ Por. T. R o z k r u t, Dowody..., s. 309. 
Należy zauważyć, co zaznacza Jan Paweł II w swoim przemówieniu do Roty Rzymskiej z 1989 roku, aby jawność kanonicznego postępowania procesowego $\mathrm{w}$ procesie o nieważność małżeństwa nie wykraczała poza jej poufną naturę ${ }^{91}$. Sędzia kościelny winien, na ile to możliwe i zgodne z normami prawa kanonicznego, zagwarantować ochronę intymności w prowadzonym procesie małżeńskim. Szukanie prawdy obiektywnej o danym małżeństwie nie może bowiem zdradzić zaufania stron i świadków występujących w procesie. Wiąże się z tym również problem i dylemat udostępniania czy też nie udostępniania sądom cywilnym akt kościelnego procesu małżeńskiego. Mając na uwadze powyższe przemówienia Jana Pawła II oraz zapis konkordatu, mówiący o autonomii państwa i Kościoła katolickiego (art. 1), należy powiedzieć, że praktyka udostępniania sądom cywilnym akt procesu kościelnego byłaby raczej niezgodna z myślą Kościoła ${ }^{92}$.

Możemy zatem powiedzieć, że z odmową prawa do obrony mamy do czynienia wówczas kiedy sędzia nie umożliwi stronom przejrzenia akt w siedzibie trybunału, a przynajmniej nie uczyni tego w takim zakresie, w jakim jest to możliwe biorąc pod uwagę konieczność utajnienia niektórych z nich. Konieczne jest i bardzo ważne, aby strony procesowe wiedziały, iż postępowanie procesowe zmierza ku końcowi, że środki dowodowe zostały zgromadzone i że mają prawo zapoznania się z nimi w miejscu i terminie wyznaczonym przez sędziego.

\subsection{Faza dyskusji sprawy}

W fazie dyskusji omawiane uprawnienie ,prawa do obrony” realizowane jest głównie przez:

- prawo do przedłożenia na piśmie obrony ${ }^{93}$,

- prawo do repliki na głos adwokata strony przeciwnej lub obrońcy węzła małżeńskiego ${ }^{94}$,

${ }_{91} \mathrm{~J}$ o a n n e s $\mathrm{P}$ a u 1 u s II, Ad Romanae Rotae auditores, officiales et advocatos coram admissos (26 Ianuarii 1989)..., s. 925; Por. T. R o z k r u t, Ochrona sqdowa praw wiernych - szczegótowe zagadnienia wybrane..., s. 113.

${ }_{92}$ T. R o z k r u t, Ochrona sqdowa praw wiernych - szczegółowe zagadnienia wybrane..., s. 113-114.

${ }_{93}$ Kan. 1601 KPK; DC, art. $240 \S 1$.

${ }^{94}$ Kan. $1603 \S 1$ KPK; DC, art. $242 \S 1$. 
- prawo do przedłożenia innych dokumentów czy opinii biegłych, które powinny zostać opublikowane zgodnie z kan. $1600^{95}$,

- gdyby sędzia nie dał odpowiedniego czasu na przedstawienie uwag lub gdy były przedstawione, a sędzia je odrzucił, mamy do czynienia $\mathrm{z}$ nadużyciem prawa do obrony, a co za tym idzie, można zaskarżyć sentencję z kan. $1620 \mathrm{nr} 7 \mathrm{KPK}^{96}$.

Jak nakazują przepisy prawa kanonicznego, kan. $1601 \mathrm{KPK}$ oraz art. $240 \S 1$ instrukcji Dignitas connubii, po zamknięciu postępowania dowodowego sędzia powinien wyznaczyć odpowiedni okres czasu, aby zostały przedstawione pisemne obrony i uwagi. Wyznaczenie przez sędziego odpowiedniego okresu czasu stanowi fundamentalny punkt zachowania prawa do obrony, które przysługuje stronom $\mathrm{w}$ procesie. Zgodnie z instrukcją procesową strony nie mają obowiązku udzielenia odpowiedzi na uwagi obrońcy węzła małżeńskiego czy też strony przeciwnej, ale posiadają prawo do takiej odpowiedzi i nikt tego prawa nie może ich pozbawić. Dlatego sędzia ma obowiązek wyznaczyć określony czas, instrukcja określa go jako „krótki”, ${ }^{\prime}$, aby strony mogły $\mathrm{z}$ tego prawa skorzystać. Jednocześnie, jak zaznacza instrukcja w art. 242 § 2, mają prawo do przesłania uwag jedynie raz, chyba że sędzia z poważnej przyczyny uzna, iż należy je przyznać ponownie.

W dyskusji sprawy to obrońca węzła małżeńskiego, zgodnie z art. $243 \S 1$ instrukcji, ma prawo być wysłuchany jako ostatni. Wtedy mamy do czynienia z naruszeniem prawa do obrony, jeśli nie został wyznaczony stronom określony czas na przesłanie uwag lub jeśli sędzia odmówił przyjęcia takowych uwag. Oznacza to, że jeśli strony nie przygotują uwag w wyznaczonym terminie albo zdadzą się na wiedzę i sumienie sędziego, w myśl art. $245 \S 2$ instrukcji Dignitas connubii, sędzia może natychmiast, po uzyskaniu uwag obrońcy, przystapić do ogłoszenia wyroku. Sędzia zatem nie ma obowiązku przynaglać czy przypominać stronom o udziale $\mathrm{w}$ dyskusji, jednakże zawsze winien zażądać uwag obrońcy węzła małżeńskiego ${ }^{98}$. Jeżeli adwokaci zaniedbują przedstawienie w użytecznym czasie obron, strony powinny zostać o tym powiadomione przez sędziego i zachęcone do osobistego

${ }_{95} \mathrm{~W} . \mathrm{K} \mathrm{r}$ a i ń s k i, Prawo do obrony w procesie o stwierdzenie nieważności matżeństwa..., s. 351.

96 Tamże, s. 352.

${ }^{97}$ Zob. DC, art. $242 \S 1$.

98 Por. kan. 1606 KPK; DC, art. $245 \S 2$. 
działania w wyznaczonym czasie lub za pośrednictwem nowego adwokata legalnie ustanowionego ${ }^{99}$.

3.4. Faza decyzyjna i zaskarżająca sentencję

W myśl kan. 1614 KPK oraz art. 257 § 1 instrukcji Dignitas connubii, wyrok nie posiada żadnej mocy prawnej przed jego ogłoszeniem, chociażby nawet część rozstrzygająca wyroku została za zezwoleniem sędziego podana do wiadomości stron procesowych. Prawo do obrony w fazie decyzyjnej procesu o stwierdzenie nieważności małżeństwa odnosi się do publikacji wyroku. Jest ona konieczna dla zagwarantowania stronie możliwości poznania uzasadnienia wyroku, o której mówi kan. 1612 § 3 KPK, a co w konsekwencji oznacza możliwość złożenia stosownej apelacji. Wyrok nabiera więc mocy prawnej dopiero wraz z jego publikacją ${ }^{100}$. Ogłoszenie, czyli powiadomienie o wyro$\mathrm{ku}$ - zgodnie $\mathrm{z}$ art. $258 \S 1$ instrukcji - powinno być dokonane przez doręczenie go stronom lub ich pełnomocnikom, albo przez przesłanie im egzemplarza wyroku ${ }^{101}$. Na konieczność opublikowania wyroku bardzo mocno - jak to już wspomniano - zwrócił uwagę Jan Paweł II w przemówieniu do pracowników Roty Rzymskiej z 1989 r. Zapytał wprost: ,jak mogłaby jedna ze stron bronić się na stopniu apelacyjnym przeciwko wyrokowi wydanemu przez trybunał niższego stopnia, jeżeli byłaby pozbawiona prawa do poznania jego motywów zarówno prawnych (in iure), jak i faktycznych (in facto)?"102

Zgodnie z kan. 1630 KPK oraz art. $281 \S 1$ instrukcji termin złożenia apelacji liczy się od dnia otrzymania wiadomości o ogłoszeniu wyroku. Jednocześnie, co jest bardzo ważne, sędzia ogłaszając wyrok winien, dla zagwarantowania prawa do obrony strony procesowej, wskazać konkretne środki przy pomocy których może być on podważony. Winien również, w myśl art. 257 § 2 instrukcji, wskazać trybunał Roty Rzymskiej jako trybunał apelacyjny II instancji dla wszystkich sądów I instancji. Przypomniał o tym również Jan Paweł II we wspomnianym przemówieniu wskazując, że w celu jeszcze lepszego zagwa-

99 DC, art. 245 § 1; Por. A. D z i ę g a, Sprawy wpadkowe, publikacja akt, dyskusja sprawy (art. 217-245)..., s. 125-126.

100 DC, art. $257 \S 1$.

101 DC, art. 130.

$102 \mathrm{~J}$ o a n n e s $\mathrm{P}$ a u $1 \mathrm{u} \mathrm{s}$ II, Ad Romanae Rotae auditores, officiales et advocatos coram admissos (26 Ianuarii 1989)..., s. 926. 
rantowania prawa do obrony, ogłoszony wyrok winien wskazać środki, za pomocą których można go podważyć ${ }^{103}$.

W świetle tego co powiedziano, nie jest do przyjęcia praktyka stosowana w niektórych sądach kościelnych polegająca na przekazywaniu stronom jedynie części decyzyjnej wyroku lub podawanie informacji o możliwości przejrzenia wyroku w siedzibie trybunału albo wskazanie, iż strona może otrzymać kopię wyroku po uprzednim zgłoszeniu takiej prośby. Należy bowiem pamiętać, iż przesłanie stronom całej treści wyroku jest niezbędne w perspektywie złożenia ewentualnej apelacji, gdzie strony mają możliwość ustosunkowania się do motywacji i uzasadnienia zawartego $\mathrm{w}$ wyroku.

W tym miejscu trzeba wspomnieć o środkach zaskarżenia wyroku. Otóż wyrok sądowy rozstrzygający spór stwarza domniemanie prawne, że jest on ważny i sprawiedliwy. Może się jednak zdarzyć, że wyrok wydany przez sędziego kościelnego będzie nieważny, np. z powodu pominięcia istotnych przepisów procesowych, albo niesprawiedliwy, na skutek złej oceny stanu faktycznego lub naruszenia prawa materialnego spowodowanego błędną wykładnią lub niewłaściwym zastosowaniem tegoż prawa. Możliwość zaistnienia takich sytuacji spowodowała, że prawodawca kościelny ustanowił przepisy umożliwiające osobie pokrzywdzonej zaskarżenie wyroku ${ }^{104}$. Istnieją dwa zwyczajne środki zaskarżenia wyroku: apelacja do wyższego sędziego i skarga o jego nieważność. W imię należnego stronom procesowym ,prawa do obrony” przysługuje im prawo do apelacji, czyli prawo odwołania się od wyroku wydanego $\mathrm{w}$ instancji niższej do sądu instancji wyższej z prośbą o ponowne rozpatrzenie sprawy i uchylenie lub zmianę krzywdzącego wyroku $^{105}$. Należy pamiętać, że odmówienie stronie prawa do obrony, jak to już wspomniano, powoduje z mocy samego prawa (kan. 1620 nr 7 KPK), nieusuwalną nieważność wyroku. Nie powinno się zatem apelować od nieważnego wyroku. Jednak można to uczynić dopóki ta nieważność nie zostanie prawomocnie stwierdzona ${ }^{106}$. Innym środkiem

103 Zob. kan. 1614 KPK; J o a n n e s $\mathrm{P}$ a u 1 u s II, Ad Romanae Rotae auditores, officiales et advocatos coram admissos (26 Ianuarii 1989)..., s. 927.

104 R. S z t y c h m i 1 e r, Prawo do obrony w procesie kanonicznym..., s. 802.

105 Zob. DC, art. 279 § 1; Zob. M. G r e s z a t a, Zaskarżenie wyroku, proces dokumentalny, w: Proces małżeński według instrukcji „Dignitas connubii”..., s. 151157.

${ }^{106}$ R. S z t y c h m i l e r, Prawo do obrony w procesie kanonicznym..., s. 803. 
zaskarżenia wyroku jest skarga o jego nieważność. Możliwa jest ona w kilku sytuacjach i zgodnie z art. 271 instrukcji Dignitas connubii może być zgłoszona drogą skargi lub drogą zarzutu ${ }^{107}$.

Norma kan. $1620 \mathrm{nr} 7 \mathrm{KPK}$, jest fundamentalna w omawianym temacie, gdyż wyraźnie chroni prawa człowieka do obrony oraz wskazuje, że prawo to jest naturalnym prawem stron w procesie. Powstaje pytanie co należy rozumieć pod pojęciem „odmówienia” prawa do obrony. Ks. prof. R. Sztychmiler, za ks. prof. G. Erlebachem, stwierdza, że należy brać pod uwagę następujące elementy: ciężkość naruszenia prawa do obrony, miejsce jego złamania, czyli etap procesu oraz fakt naruszenia tego prawa w stopniu istotnym, ,może to zatem być całkowite wykluczenie prawa do obrony, jak też wykluczenie częściowe, ale w stopniu istotnym"108.

\section{Zakończenie}

Podjęty temat wykazał i uświadomił, jakie są racje i sens ,prawa do obrony" w kanonicznym procesie o nieważność małżeństwa. Przede wszystkim wynika ono z prawa naturalnego i jest ściśle związane z godnością osoby ludzkiej, której uznanie wymaga uszanowania i obrony jej praw. Każdy człowiek ma prawo do obrony. Prawo to należy do uprawnień związanych z osobą ludzką i wyprzedza każde prawo stanowione. Jest prawem podstawowym i fundamentalnym wynikającym z istnienia innych fundamentalnych praw, których ochrona powinna być zagwarantowana w Kościele. Zachowanie tego prawa wynika nie tylko z fundamentalnych praw osoby, ale jest konieczne dla realizacji sprawiedliwości procesu, której istotą jest wydanie sprawiedliwego, a więc opartego na obiektywnej prawdzie, wyroku dotyczącego danego małżeństwa.

Omawiane „prawdo do obrony” ma nie tylko oparcie w prawie naturalnym, ale ma szczegółowe odniesienie do kanonicznego prawa procesowego. Normy tego prawa gwarantuja stronom procesowym nienaruszalne prawo do obrony w sprawach o nieważność małżeństwa, prawo to promują i podkreślają jego ważność, znaczenie oraz precyzyjne i wnikliwe stosowanie dla wyjaśnienia prawdy obiektywnej pro-

${ }_{107}$ Zob. M. G r e s z a t a, Zaskarżenie wyroku, proces dokumentalny, w: Proces małżeński według instrukcji „Dignitas connubii”..., s. 146-151.

${ }^{108}$ R. S z t y c h m i 1 e r, Prawo do obrony w procesie kanonicznym..., s. 803. 
wadzonego procesu. Kanoniczne prawo procesowe wyróżnia dwie dystynkcje: prawo do obrony oraz wykonywanie prawa do obrony. Strony procesowe mają zagwarantowane prawo do obrony we wszystkich fazach procesu: wszczęciu i zawiązaniu sporu, w fazie dowodowej, dyskusji oraz decyzyjnej i zaskarżającej wyrok. W wykonywaniu prawa do obrony strony mogą posiłkować się takimi figurami procesowymi jak: kurator, pełnomocnik i adwokat. Ważne jest, aby w procesie o nieważność małżeństwa została zachowana zasada sporności procesu, która wymaga zachowania prawa do obrony każdej ze stron. Gwarancje te dotyczą w szczególny sposób aktu cytacji, powiadomienia o przedmiocie sporu, możliwości prezentowania różnych środków dowodowych, publikacji akt sprawy i publikacji wyroku.

Prawo do obrony pozwala również dotrzeć do prawdy o ważności zaskarżonego małżeństwa i wydać sędziemu wyrok. Kryterium inspirującym posługę każdego sędziego w procesie kanonicznym - jak stwierdza Jan Paweł II w przemówieniu do Roty Rzymskiej w 2005 roku - jest jego umiłowanie prawdy. Nie może się jej bać, ulegając bojaźni niezaspokojenia czyichś oczekiwań lub aspiracji ${ }^{109}$. W procesie o nieważność małżeństwa ważna jest prawda obiektywna o danym małżeństwie. Dlatego „każda sentencja sprawiedliwa orzekająca ważność lub nieważność małżeństwa umacnia kulturę nierozerwalności zarówno w Kościele jak i w świecie" ${ }^{110}$. Stąd sędzia kościelny powinien szukać przede wszystkim prawdy o małżeństwie, nie może zaś dać się owładnąć fałszywej formie „miłosierdzia”111.

Prawo do obrony ma również zagwarantować wiernym prawo poznania prawdy o ich małżeństwie. Prawo to należy zawsze interpretować w kontekście obowiązku, jaki mają strony odnośnie poszukiwania prawdy obiektywnej o ich małżeństwie. Nie oznacza ono prawa do nieważności małżeństwa lub prawa do jego ważności. Oznacza natomiast

109 Por. J o a n n e s $\mathrm{P}$ a u 1 u s II, Ad Romanae Rota auditores, oficiales et advocatos coram admissos (29 Ianuarii 2005), AAS 97(2005), n. 5, s. 166.

$110 \mathrm{~J}$ o a n n e s P a u 1 u s II, Ad Romanae Rotae tribunal (28 Ianuarii 2002), AAS 94(2002), n. 7, s. 345.

111 Tamże; Ciekawe rozważania na temat tożsamości sędziego kościelnego snuje ks. prof. R. Sobański, które w tym miejscu wypada zauważyć i wnikliwie przeczytać, gdyż ukazują dylematy sędziowskie, jak też stan polskiego sądownictwa. Zob. R. S o b a ń s ki, Uwagi o tożsamości sędziego kościelnego, Prawo Kanoniczne 45(2002) nr 3-4, s. 3-22. 
zagwarantowanie stronom ich podstawowych praw procesowych, do których zalicza się prawo złożenia zeznań i innych oświadczeń, prawo przedstawienia dowodów, prawo poznania akt procesu oraz prawo przedstawienia stosownych obron czy zaskarżenia wyroku ${ }^{112}$.

\section{Arguments and sense of the "right to defence" in process for nullity of matrimony}

"Right to defence" in canonical process for nullity of matrimony results first of all from natural right and it is strictly connected with the dignity of human being, recognition of which requires to respect and defend human's rights. Each man has a right for defence. This right belongs to the rights related with human being and it precedes each codified statutory law. It is basic and fundamental right resulting form existence of other fundamental rights, protection of which should be guaranteed in the Church. Keeping this right is necessary for realization of justice and objectivity of the process.

Norms of this law guarantee to the litigants inviolable right to defence in cases for nullity of matrimony, they promote this right and underline its importance and meaning as well as its precise application to clarify the truth of objectively conducted suit. Canon process law distinguish two distinctions: right to defence and exercising the right to defence. Litigants have the rights to defence guaranteed in all stages of the suit: starting the proceedings and initiation of dispute, in stage of showing the evidence, discussion as well as in decision stage and attacking the judgment phase. Exercising the right to defence the litigants can support themselves using such suit figures as: guardian, attorney in fact and lawyer. It is important, so as in the suit for nullity of the matrimony, a contention suit rule was kept, which requires keeping the right for defence to each litigant. These guarantees apply in special way to citation act, notifying about subject of dispute, possibility to present different evidence means, publishing the records of the case, presentation of applicable defences, publication of sentence and its appeal.

Right to defence also allows the tribunal conducting the case to get to the truth about validity of questioned matrimony and to pass the sentence by the judge. Furthermore it guarantees to the faithful the right to know the truth about their matrimony. This right should be always interpreted in context of duty the litigants have regarding searching for objective truth about their marriage. This means guaranteeing to litigants their basic process rights.

112 Por. J o a n n e s P a u 1 u s II, Ad Romanae Rota iudices habita (22 Ianuarri 1996), AAS 88(1996), n. 3, s. 775. 